\title{
V.V. Ganeshananthan's Love Marriage and Monica Ali's Dinner with Dr.Azhad: Storying Memory, Trauma and Identity
}

\author{
Maria Assif \\ English Department \\ University of Toronto Scarborough, Canada
}

Received: 09-11- 2013

Accepted: 16-12- 2013

Published: 10-01- 2014

doi:10.7575/aiac.ijclts.v.2n.1p.1

URL: http://dx.doi.org/10.7575/aiac.ijclts.v.2n.1p.1

\begin{abstract}
At the intersection of trauma, identity, memory, and narrative theories, this article examines the main female narrators of V.V. Ganeshananthan's Love Marriage and Monica Ali's "Dinner with Dr.Azhad," as they encounter varying forms of traumas that distort their perceptions of the world and lead them to question their own identities. This distortion changes the personal narratives they have created about the world, requiring them to reconstruct it in order to incorporate these traumatic experiences and form a coherent narrative on which they will be able to identify themselves and ultimately construct their own selves.
\end{abstract}

Key words: South Asian Literature, Mona Ali, V.V. Ganeshananthan, Trauma, Memory, Storytelling

\section{Introduction}

The definition of trauma and the individuals whom it affects have varied throughout history, constantly changing and being altered in response to events taking place. The 5th edition of the Diagnostic and Statistical Manual of Mental Disorders (DSM-V) describes trauma as originating from an event that "must in some way be extraordinary, outside the range of normal human existence." While DSM-V details some of the symptoms of trauma, it falls short in accounting for traumas that take place outside "the range of normal human existence." One scholar who attempts to go beyond the confines of this strict definition is feminist therapist, Mari Root. She develops the concept of "insidious trauma""traumatogenic effects of oppression that are not necessarily overtly violent or threatening to bodily well-being at the given moment but that do violence to the soul and spirit" (Caruth 107). This definition accounts for situations that are traumatic because they go against one's personal beliefs and have traumatic outcomes, though they are inside "normal human existence" and are not ostensibly traumatic (Hunt 8). Root's concept is a key framework for this paper, which attempts to present a fresh perspective on two South Asian fictional works rarely mentioned in literary criticismVasugi V. Ganeshananthan's novel Love Marriage (2008) and Monica Ali's short story "Dinner with Dr. Azhad" (1967). In both texts, the main female narrators encounter varying forms of traumas that distort their perceptions of the world and lead them to question their own identities. This distortion changes the personal narratives they have created about the world, requiring them to reconstruct it in order to incorporate the traumatic experiences and form a coherent narrative on which they will be able to identify themselves. Therefore, although both characters are in different environments, the specific types of identity transformations they in turn parallel the re-evaluation of their memories in an attempt to rebuild their personal narratives and ultimately their own selves. Such discussion comes at the intersection of trauma, identity, memory, and narrative.

Identity is described by Stuart Hall in Memory, Narrative and Identity as "neither simple nor stable." Instead, it "is always a structure that is split; it always has ambivalence within it." In preferring to see it as a "process of identification" rather than as "one thing, one moment," Hall conceptualizes identity as "something that happens over time... that is subject to the play of history and the play of difference." Thus identity, instead of being seen as fixed, becomes a dynamic construction that adjusts continually to the changes experienced within and surrounding the self (16). This allows us to discuss the changing aspect of identity and its ability to be influenced by mitigating factors, such as society and the environment. The "process" by which this identification takes place is dependent on the environment, socio-economic status, membership into a social group, and many other factors in an individual's daily life. Through this process, as Hall mentions, is the "play of history and the play of difference", allowing for the interplay of memory to take place. The variety of events which structure our identity "intersect in us to create our individuality and form a net of language that we share with the community... [called a] collective memory" (Singh et al. 17). Collective memory, just like individual memory, is a function that is able to change and evolve with time and circumstances. It is these memories that link us to the events taking place in our lives, permitting our consciousness to connect events and experiences to form a net of language we can associate with. However, when we encounter traumatic events, identified by the DSM-V as "outside the range of normal human existence," our consciousness attempts to incorporate them into our memories, further merging with our identities. However, as it is "outside of normal" experience, difficulties arise. Narratives that we construct from daily experiences and memories are initially unable to incorporate traumatic events that are clearly outside of their boundaries. It is in this sense that the narrators of Ganeshananthan's Love Marriage and Ali's "Dinner with Dr. Azhad" struggle and soon grow. From their process of 
incorporating the various traumatic events into their personal narratives, we are able to see the variety of coping methods they present and the ways their self-perception and self-narration is shaped by these traumas.

Another framework that can shed further light on these narrative layers is the 1990's scholarship, with ethnic texts as its subject, as it has asserted the importance of memory for ethnic writers in the negotiation of identity, such as the two collections by Amrijit Singh, J. T. Skerrett, Jr. and R. E. Hogan (eds.), Memory, Narrative, and Identity: New Essays in Ethnic American Literatures and Memory and Cultural Politics: New Approaches to Ethnic American Literatures; and Michael Fischer's Ethnicity and the Post-Modern Arts of Memory. Such an emphasis is useful for the way that it allows us to read what the text does not say, as much as what it does. The insistence upon the workings of memory as incomplete, flawed, subjective, and maybe ahistorical, may open the way to acknowledge certain tacit textual layers, such as silence or forgetting, not accounted for within conventional theories of the representation of the past. In this context, memory shapes narrative forms and strategies toward reclaiming a suppressed past and helps the process of revisioning that is essential to gaining control over one's life and future. The ethnic narrative thus becomes, in Stuart Hall's phrase, "an act of cultural recovery," and the emergent ethnicity embedded therein develops a new relationship to the past, which is to be recovered through both memory and narrative. As Ben Xu puts it in "Memory and the Ethnic Self: Reading Amy Tan's The Joy Luck Club", "Our sense of what has happened to us is entailed not in actual happenings but in meaningful happenings, and the meanings of our past experience . . are constructs produced in much the same way as narrative is produced" (15).

\section{Memory, History and Identity in Love Marriage:}

Indeed, V.V. Ganeshananthan's Love Marriage is a novel that is concerned with the recreation of family ties through stories the discovery of memories. The narrator Yalini, a student in an American university, finds herself torn between the external western culture she grows up in and the Sri Lankan practices of her household which also consists of news accounts of the civil war taking place in Sri Lanka between the Tamil and Sinhalese populations adding further tension in her home. Then suddenly, after a phone call from her mother, Yalini finds herself in the Tamil populated community of Scarborough, Ontario north of the border in Canada. Her family has temporarily taken residence there to nurse her cancer-stricken uncle Kumaran - a previous member of the Liberation Tigers of Tamil Eelam (a terrorist group according to the Canadian government), who are fighting for the independence of Tamil Sri Lankans in a Sinhalese run country. Through a series of conversations with Kumaran, Yalini imparts the history of her family and the war which has affected their homeland. In addition to these flashbacks, Yalini also narrates the marriage of her cousin and Kumaran's daughter Janani, as well as her own experiences in a society that greatly contrasts from her own American lifestyle.

Although Yalini has created for herself a working identity by forming a "net of language," within this net, we see traces of repressed memories and the difficulty she has incorporating the contrasting realities of war-stricken Sri Lanka and peaceful America. When she says that she "left [her parents'] war-torn house in our peaceful country," the extent of the juxtaposition which she must make in order to have an identity within this country is visible. (Ganeshananthan 21). When recalling the memories she has at home, mental images arise from the newspapers she used to read without the knowledge of her parents, graphically depicting the gruesomeness of the war taking place in Sri Lanka and her parents' very visible attempt at repressing any such memories for the sake of their peaceful home in America. In response to this natural curiosity, Yalini attempts to connect with her roots and understand the events which are taking place building upon the historical and contextual knowledge she has gained from print sources such as those newspapers from childhood. However, once she enters her American lifestyle, she begins to compare the contrasting images of human war torture and must create a working identity in order to effectively function in society — described as follows:

[She] looked around this American university library and noted its fire alarms and fire extinguishers. Security personnel stood at each entrance. This library was well guarded, if not well loved. In Jaffna, many irreplaceable, single-copy manuscripts had burned. As a child, I had imagined it many times, in each library I had entered - men in uniforms, laughing, with torches and gasoline and guns. How each shelf would fall into, and break the one below it, wood blackening and metal melting. How the cover of one book would embrace the one beside it, touching it gently, so gently, with a ring of sparks (Ganeshananthan 24).

These memories that rise up when in a library are a clear indicator of the trauma she experiences due to repressed memories. Her conjuring of this childhood memory of the Jaffna library burning while she is at her University library shows how "symbolic indirect indications" such as the security guards protecting the books and the fire extinguishers, alert her and us to the "assumed existence" of a memory that has been "pushed downward into the unconscious" (Caruth 168). These memories Yalini experiences are not hers but her father's. He is the directly traumatized individual who had closer ties to the Jaffna library and would therefore be able to envision it. In this sense, the trauma Yalini experiences is equivalent to the primary experience her father has had, depicting the ability of trauma to transfer between individuals. Although Yalini is a predominantly American child, she recognizes her Tamil roots by listening to her father's stories; this common Tamil link between them serves as a route for the transference of trauma from father to daughter. Even as Yalini grows from this child who is traumatized by the story her father told her of the burning of the Jaffna library to a young adult in university, she realizes that "no matter how American [she] was, [she] was also the only Sri Lankan" (Ganeshananthan 21). Yalini's inability to create for herself an effective narrative that is a juxtaposition of her Sri Lankan household and the American lifestyle is exemplary of how trauma has been embedded in her life since childhood, especially without even experiencing these events first-hand.

Upon entering the Tamil-populated Scarborough, Ontario, the drastic change in environment Yalini feels allows her to experience the traumatic memories she occasionally has on a collective scale. It is the presence of a large Tamil 
population in Scarborough that allows them to form a community, socially marginalized individuals develop a collective identity, as well-described by the sociologist, Paul Connerton:

Different details will emerge because they are inserted, as it were, into a different kind of narrative

home. It is essential in perceiving the existence of a culture of subordinate groups to see that this

is a culture in which the life histories of its members have a different rhythm and that this rhythm

is not patterned by the individual's intervention in the working of the dominant institutions (19).

Once in Scarborough, Yalini is able to perceive the extent to which the civil war in Sri Lanka is affecting the diasporic Tamil community - especially second generation Tamils like herself. She writes that she "knew about the war and could guess at what it had taken from [her] parents ... but [she] had never thought it could take anything away from [her] (Ganeshananthan 37). She was unable to envision a collective identity when in her American home with no one to ethnically connect with. Eventually, as she begins to converse with her cancer-stricken uncle Kumaran and attempts to create a relationship with her repressive cousin Janani, Yalini will see how the war will affect even her, a born and raised American citizen.

Kumaran's desire to speak with Yalini and impart to her the memories of his past, which are depicted in the numerous recounts, not only serve the purpose of affecting the way she views her world, but also a method to provide therapy for the traumatized Kumaran who is in his last days. When Yalini takes care of her uncle and listens to the stories and narratives he has to impart, she is taking on the role of a therapist, interviewing her patient so that he may be able to let go of the trauma. In a poignant and nuanced narrative instance in the novel, such a complex relationship is depicted:

he could no longer turn the page of a book, or write a letter, I would do it for him. He would tell me: write it down. I told you a story that no one should have to know. Write it down, write it down. I knew that no doctor should ever have to do this, and I knew that I would do it, because in the end, what he wanted was what anyone wants: to die in the presence of family, with no need for shame or secrets (Ganeshananthan 138).

Aside from wanting to take on a career as a doctor, Yalini's role surpasses that of a niece, but it is this intimacy she holds with Kumaran, where by the end of his life he is comfortable enough to impart to her details of his past in the terrorist group and his journey towards it, that transposes trauma onto Yalini herself. This trauma she experiences due to self-exposure is called "vvicarious traumatisation' and relates to both the effects on researchers and on clinicians who treat traumatized people" (Hunt 48). The possibility of trauma being transferred between individuals based on the level of exposure, acknowledges many of the traumas experienced by Yalini, allowing for a solid analysis of her situation and a sound process of reconstruction. In order to avoid any form of vicarious traumatisation within a professional therapeutic setting, the theorist is advised to be aware of the material he or she is to be exposed to, and not to become "too involved" with the patient, while a degree of empathy is always important (Hunt 48). However, Yalini is in a playing field that greatly contrasts with the impersonal position a psychologist may have to his patient. While Hunt writes that "the person who is traumatized needs help and guidance to be able to discuss their problems - not someone to share their misery," Kumaran's decision to converse with Yalini and provide her with recollections of his memory is not solely for his recovery but to offer her the memories he has of a culture that is soon disappearing, as more and more ethnic Tamils migrate to western countries (Hunt 48). Kumaran's repeated orders to write down the stories he has imparted to her raise the importance of the narratives he is telling her--narratives of memories of how their family members came to be and the impact of the civil war on their loves.

The role which narratives play in the depiction of Kumaran's trauma and the incorporation of this trauma into Yalini's own identity is seen through the recounts that embody the entire novel and their ability to merge together as a common identity. "Clinicians and researchers regularly encourage traumatized or bereaved people to develop narratives about their experiences, to help them make sense of, and hopefully learn from, their experiences" (Hunt 91). It is this intention that gets Kumaran to open up to Yalini, a desperate attempt to rid himself of the numerous secrets and guilt he does not want to carry with him to death. However, through vicarious traumatization, Yalini soon becomes infected with the trauma, seen in her ability to perceive aspects of her parents, her life, and society she had failed to notice before gaining knowledge of the war and her family's background. Her belief that a civil war half-way across the world would affect her parents but not her, has been shattered with the wave of narratives she encounters in her sessions with Kumaran. She is driven to re-evaluate the personal narrative she had meticulously created for herself balancing between American peace and Sri Lankan civil war.

Due to the malleability of identity, Yalini is driven to reconstruct her personal narrative so that she may incorporate all the new information she has received and create for herself a working identity that accommodates all the changes she has experienced. Hunt elaborates on the topic of personal narrative as follows:

We select and organise our personal memories to build a coherent sense of the self and establish and maintain our identities ... personal stories are not just about telling stories; they are the means by which identities can be fashioned and developed. People need to make meaningful sense of their experiences through the use of language and stories. This relationship between narrative, self and identity is central to our understanding of the response to trauma, and links with the social constructions that help to build notions of self and identity. ... Narrative research helps us to explore how the self is developed out of our cultural resources (or social constructs), and how we believe that our lives need to have a certain shape or structure (narrative) which has personal identity at the core. In this sense, narrative is the performance of the self in the sense of selfidentity (115). 
Narratives therefore allow individuals to create a connection between the events that happen, forming an identity in this process. As Hunt writes, these stories do not simply offer accounts of an event but portray the identity of the narrator they depict the beliefs and values an individual will have, reveal his status, and many other qualities specific to that individual's identity. Also important within this excerpt is the focus on the structure required for identity. The merging of social constructs or cultural resources with narrative connotes to the multifaceted process of forming an identity and further exemplifies its ability to be influenced by external forces. Reflecting Hall's statement that identity is a continually changing entity affected by internal and external changes, the traumas experienced are the stimuli which lead to a collapse of the structure of narrative. Consequently, "the personal identity at the core" of the narrative structure also collapses, placing great emphasis on successfully constructing a narrative that integrates all aspects of social constructs in order to minimize the chance of collapse.

The ambivalence of identity that Stuart Hall describes in the earlier portions of this analysis, is evident in Yalini's attempt to incorporate the traumas she has encountered into an identity that will support it. The narrative Yalini previously had was of a naïve young American, who believed that due to her birth in a foreign land would not be affected by the ethnic war taking place in the land of her ancestors. She believed that once she left for college and her "war-torn" home for an American university, she would be able to separate herself from the conflicting immigrant identity. However, once she is in Scarborough, she cannot escape the obvious presence of a Tamil population that maintains strong opinions on the events taking place in Sri Lanka. She encounters a collective community that has a strong identity and memories of the war. Her sessions with her uncle give her the tools necessary to incorporate the Tamil identity she has struggled with in the U.S.

These tools are the memories Yalini comes into contact with--a form of collective memory and subjective recollections about the events that took place in Sri Lanka, which through her interviewing skills Yalini transforms into objective historical facts. When referring to the difference between history and memory, Maurice Halbwachs On Collective Memory writes:

history begins where social or collective memory stops operating. He argues that there is only one objective history, but many collective memories. Collective memories are confined to the most recent past (the lifetime of the people in the society) and are valid only for people within that society. History is the academic objective study of the past, whereas there are collective memories of the past which are shared by communities and which are specific to that community, i.e. are subjective (Hunt 99).

This distinction between collective memory and history is extremely relevant to immigrant groups, as they share memories within their communities in attempt of preserving the experiences they have had. However, although Halbwachs clearly states that these collective memories are subjective, so are the academic histories. History does not write itself, and the individuals putting it down on paper allowing it to be one step closer to permanence are also from a certain community with its own set of collective memories. In addition to this, there is also conflict regarding the portrayal of history due to the belief that it is usually the victors who solidify historical accounts, later taught in schools and this becoming academic. Therefore, even though history tends to be thought about as more objective than collective memory, it still contains traces of subjective historical interpretation. The difference between these two, the memories and history, is the permanence of the latter. History is written and recorded while collective memories are verbally shared among the community. The unchanging aspect of history also leads it to be more objective in contrast to the unwritten collective memories of society, constantly changing in response to its narrator and environment.

The stories Yalini has been hearing are collective memories from her uncle, her aunt Kalyani, her mother, father and other individuals in the new Scarborough community. These stories are subjective and provide only a one-sided account of an event. However, it is this strong opinionated tone that allows for the creation of a Tamil identity as victims within the civil war. Many of Yalini's Tamil acquaintances perceive themselves to have been cast out and must actively work toward the continuation of their disappearing culture by passing on stories and further memories. These memories however, as Halbwachs elaborates, are "confined to the most recent past (the lifetime of the people in the society)" which is very relevant in Yalini's case, as she is hearing first-hand accounts with encounters in the war and it's direct effects. Kumaran's recollections go as far as before the Liberation Tigers group was even established to offer her information on the many resources and influences present that led to the present day civil war. Nevertheless, these points are "valid only for the people within the society" easily seen through the victim perspective that many of the narratives portray. They create for themselves a net of language out of these collective memories that they are soon able to offer Yalini.

Yalini's constant writing places her in favour of history, an objective belief that she will be able to carry back with her to the United States. Hunt supports this point by saying that "history is reinforced by writing, collective memory is reinforced by social occasions such as rites and commemorations" (107). Due to the scarcity of a Tamil community in Yalini's American home, the best way to carry with her all the knowledge she has gained is transcribing it, just as Kumaran had previously advised, and transforming it into something solid. Her mother, however, is unable to grasp the importance of constantly writing, as she asks: "Why are you writing that down? ... There's no need to keep an old grudge" to which Yalini replies: "For history. To know, I say...I'm not keeping the grudge, I protest. I'm just recording it. They do not understand this: history" (Ganeshananthan 243). It is this history she knows that will allow her to understand the events taking place in Sri Lanka and decide where she stands as a person among all the conflict taking place. Yalini's ability to transform the raw, subjective memories she is offered by Kumaran, which she herself doubts in many instances, into an objective history, is representative of her progress in reforming her own personal narrative to accommodate the traumas she experiences. 
By the end of the novel, Yalini's ability to incorporate an understanding of the events that took place in Sri Lanka due to the civil war and her own life, is evident from the ease in her tone when she discusses acts of murder and abductions. When reflecting on her trip, she says:

The Tamil state that exists here, [is] an island away from the island that we all remember. Even I remember that nation. And that is because of him (Kumaran). That is because I was raised in a house that could not forget it. A house where I was taught a language and a code that told me about an unofficial war. As a child I read about Tamils murdered, and a Tamil library burned. I knew a woman who, while watching the news, had seen her own mother blown up live on television. I heard stories about Tamils disappearing, Tamils tortured, Tamils killing Tamils. I learned a certain vocabulary. I learned to believe that a government could kill its own and drive them to commit unspeakable crimes. That no one would be right, but that some would be more wrong (Ganeshananthan 251).

The social continuity of Yalini's newly formed identity is clearly visible in her reflection as she confirms her own ability to "remember that nation." Important to notice is also the smooth interweave of childhood, mid-life and recent memories because when an individual encounters trauma, his memories of childhood are altered along with present beliefs because "memories of childhood can change if the current personal narrative changes. This is because childhood memories remind us of who we are now" (Hunt 116). Previously, when Yalini spoke about the gruesome details of war torture she read as a child in the newspaper, she was unable to continue her thoughts and offer a coherent image. The common American belief in the structure of the state and government which Yalini would have had prior to arriving in Scarborough has disintegrated into a bitter image of gruesome possibilities. By the end, the influx of memories encountered through the many narratives offered by Kumaran has led to a complete upheaval of her previous beliefs and a reformation of a new personal identity consisting of the collective Tamil identity and traumas experienced. Yalini's journey of incorporating the traumas she experiences into her personal identity reveals the process of recreating one's personal identity and the importance of her memories in this process. The traumas she experienced led to her memorying of them (a verb I have cointed to refer to the act of constructing and registering these traumas in her memory), due to their inability to become incorporated into her normal beliefs, and once she re-evaluated all her beliefs through life, she came upon a working personal identity for herself, seen in the previous paragraph that comfortably incorporates her traumas into her memories. This process is non-linear and different for every individual, but the essence of it (being able to start at belief threatening traumas and in the end being able to accept the trauma and move beyond it) is what every trauma survivor hopes for. It is what Monica Ali's narrator Nazneen envisions for her future. She envisions being able to get past the traumas she had experienced, gaining control over the memories that have become her accomplice, and creating for herself an identity stronger than the one that had been broken by the traumas to support and form her.

\section{A world of One's Own in "Dinner with Dr. Azhad":}

Monica Ali's short story "Dinner with Dr. Azhad" revolves around the narrator Nazneen and her daily life in London, a new city she has come to from Bangladesh after marrying Chanu. Nazneen portrays her encounter with the western world and its inhabitants through her South Asian perspective, offering visual descriptions of neighbouring characters in both a grotesque and extremely informative manner. Her husband is forty and has been in London for sixteen years. These years embody the transformation he has gone through in order to create for himself a working identity in this western society, while Nazneen clearly has some "adapting" to do. She constantly refers back to her memories of her rich father and the specific furniture they had in Bangladesh, in order to make sense of her current situation as a housewife in London. In one particular instance, dinner is set for their guest Dr. Azhad and a conversation begins on the topic of immigrants and their attempts to assimilate into society. While Chanu seizes the moment to express his success in assimilating into Western society, Nazneen is able to gain a further understanding of the traumas immigrants, such as herself, experience due to displacement.

Nazneen's ability to connect her encounters with memories of home depicts the extent of her displacement and further allows us to see the dominating role her memories play in her ability to make sense of the world. The novel representation of her surroundings when looking out of the balcony - the tattoo woman, for instance, who reveals a little too much skin is one of the many instances that situate her as an ethnic unassimilated woman. Another image is of the apartment itself and how Nazneen chooses to depict the furniture and colours in the room in relation to her present unaltered identity of Bangladeshi village girl. To a western reader, when referring to "the sofa and the chairs [as] the colour of dried cow dung," it is difficult to envision it, due to a lack of knowledge about cow dung and its colour varieties (Ali 414). However, considering that her experiences in the village are embedded into her memories and identity, this is the most natural of associations for Nazneen. Additionally, when taking in an overwhelming number of furniture present in Chanu's apartment, she realizes that even her father, who "was the second wealthiest man in the village [...], he never had anything like it" (Ali 414). Nazneen is unable to distinguish between the eastern and western cultures nor realize that the living standards and ways of life between these two areas are very different. Her only way at the moment to understand and explain the numerous furniture, is to create a correlation between them, further revealing her eastern roots.

In all these instances, Nazneen's memories serve as a boundary that keeps her within their confines through constant flashbacks and limits her ability to understand her new home from a western perspective. By elaborating on her role in the house from cleaning and cooking to making a welcome home for her husband, Nazneen has clearly made us aware of her position as a housewife. Furthermore, her inability to speak English situates her in a subordinate position in London society. Interestingly, Chanu perceives her as the young "unspoilt" Bangladeshi village girl whom he has 
married (Aziz 415). She therefore becomes his link to his home country and further allows him to create an ethnic household that will suffice his nostalgic desire of a home. As he becomes more and more assimilated into the western culture, traces of his Bangladeshi roots disappear in response to this. Nazneen, the "unspoilt village girl", symbolizes the beliefs and practices of Bangladesh through her cooking, home care, religious practice, passive attitude, and other domestic rituals. She is his reminder of the lifestyle he left in his home country, through her inability to converse with the western individuals and further providing him with a Bangladeshi environment in his home. However, for Nazneen, Chanu becomes her eyes into the social life of London, offering her images and information. Due to her lack of English fluency and contextual knowledge of the West, Nazneen is constantly seen quoting Chanu in his interpretation of the new western world she has entered. In Nazneen's constant attempt to relate her present experiences with those of her past when she was in Bangladesh, arises the image of a woman who is clearly tortured with the difficulty of creating for herself a working identity of the present.

However, the members of society Nazneen observes are merely objects of gaze; Nazneen must reconstruct her identity for do not converse with each other on a daily basis. They are unable to support each other and most importantly lack a collective identity, due to their isolation. From the apartment Nazneen lives in, she is able to see a variety of individuals, from the tattoo lady she is unable to converse with, to the "two old men in white Punjabi-pyjama and skullcaps" who are too engulfed in their own conversation (Ali 412). However, even among all these people, Nazneen is unable to connect and communicate with anyone; she cannot depend on a structure for any form of support, and in effect, is left to fend for herself. This loss of support is described by Cathy Caruth in her book Trauma: Explorations in Memory as collective trauma:

A very slow disintegration of "the basic tissues of social life...[with] a gradual realization that the community no longer exists as an effective form of support and that an important part of the self has disappeared ... "I" continue to exist, though damaged and even permanently changed. "You" continue to exist, though distant and hard to relate to. But "we" no longer exist as a connected pair or as linked cells in a large communal body (187).

The community, for an individual, serves as an entity to associate with and create a larger and stronger identity. Many people are judged on the basis of the community they reside in, and that is because of the common identity people are assumed to have in the same community. Specifically in Eastern countries, community and extended family are aspects of one's daily life, and all have a role to play. The name or status in a society is of great importance and in many instances, by tainting one's identity, the community might disown individual - a clear signal of the importance of a common identity within the community. For such immigrants, the individualistic west is unrealistic when thought about but soon becomes traumatic when experienced. There are no more extended family and close neighbours to confide in. In Nazneen's case, even though she sees her neighbours and they see her, they are unable to connect on the level of "we" - lacking a common connection and community.

The traumas Nazneen experiences are due to this multi-layered isolation she experiences. The social fabric supporting her in Bangladeshi society has been removed, exposing the instability of life and undermining her beliefs. Although she does have Chanu, he has integrated himself into the Western culture, making it difficult for her to connect with him from her present unassimilated position. Nazneen is clearly aware of her lone position within this London society as she envisions being able to go visit the tattoo lady while taking "an offering of samosas or bhajis" to which "the tattoo lady would smile and Nazneen would smile and perhaps they would sit together by the window and let the time pass more easily" (Ali 412). But after all, this is only a vision, due to the many boundaries Nazneen would encounter if she attempted to converse with the tattoo lady. Strangers might answer the door, the tattoo lady might be mad, but most importantly all Nazneen could say would be "sorry" and "thank you." Visible in her dream is the attempt to merge together the "the basic tissues of social life" that have clearly fallen apart, an aspect of Nazneen's life that she struggles with on a daily basis in her husband's lonesome apartment (Ali 413).

Due to the limited amount of social exposure Nazneen has gotten and the recent nature of her arrival in London, an analysis of Chanu's traumas will allow for a clearer understanding of the effects of displacement. The sixteen years he has been in London have allowed him to establish a position in society as a worker, a student and a member of the Bangladeshi immigrant community, such as Dr.Azhad. However, the residues of the collective trauma he felt and, at some points continues to feel, are starkly evident in his conversations during dinner. Partway into the dinner, he admits that he is forty years old and has "been in this country for nearly sixteen years:"

Nearly half of my life. When I came, I was a young man. I had ambitions. Big dreams. When I got off the airplane, I had my degree certificate in my suitcase and a few pounds in my pocket. I thought there would be a red carpet laid out for me. I was going to join the Civil Service and become Private Secretary to the Prime Minister. That was my plan. And then I found things were a bit different. [The West] did not know the difference between me, who stepped off a plane with a degree certificate, and the peasants who jumped off the boat possessing only the lice on their heads" (Ali 419).

In this passage we catch a rare glimpse of Chanu's personal narrative when immigrating to London and the trauma associated such rite of passage. The extent to which his ideals and beliefs were negated is seen in the high expectations he held for himself. To be "Private Secretary to the Prime Minister" and to have a "red carpet laid out for [him]" are dreams he created in Bangladesh in a wealthy family. The personal narrative he had had until the age of twenty-four was one of prestige, distinction and high class--a reflection of the collective identity of the community he lived in. This elite quality is further highlighted as he makes a point of the fact that he was identified with the peasants with "lice on their heads" and the tone of disbelief which accompanies it. The class separation he had in Bangladesh and elitism he 
had believed in were erased the moment he was bundled with the class-less peasants. However, even after he has spent sixteen years in London and assimilated into the culture, he perceives himself to be of high importance. His constant use of the words "I" and "my" which have been transposed here to "he" and "his," are examples of his dominating role in this narrative and the personal significance he holds for himself.

Following close behind the collapse of Chanu's belief system are Nazneen's--as she finds a place for herself in the London society, but being a woman places her in an even more disadvantageous situation. Although the collective traumas she experiences are similar to those of Chanu, her role as a housewife and the expectations Chanu places on her to be his "unspoiled village" wife may lead many readers to write off her experiences as simply those of a woman who is homesick. But as elaborated upon previously, the frequency and strength of her memories in her daily life are clearly a result of the displacement she feels and aside from simply reminding her of home, they become the boundaries that hold her back. They do not play the role of memories anymore but serve the function of supporting her understanding of her new western home. The unconventional relationship with her memories limits her chances of creating a personal narrative that is able to incorporate the changes and offer her something to identify with.

With the acknowledgment of an insidious trauma in hand, the role of memory in the traumatic recollections Nazneen has comes to the forefront of our discussion. Ali's integration of memories alongside the new experiences which Nazneen encounters, leads to a multi-dimensional reading experience where the past is clearly intertwined with the present. When Nazneen admires the plates and the amount of furniture in their small home, she conceptualizes it alongside the status of her father in Bangladesh and the great wealth which this would represent back home. At this point of the narrative, her identity is clearly tied to the eighteen years she has spent in Bangladesh and her inability to think beyond them. In such cases, the non-linear presence of memory presents a subversive, de-centering narrative effect:

memory interrupts linear, conventional narratives in order to make room for multiple voices and perspectives, ... This use of multiple voices, although not entirely unknown elsewhere in literature, becomes ... a means of creating community as part of the dialectic between the past and the present in moving toward the future (Singh et al 18).

Nazneen's dependence on the past and the comfort it provides brings to the narrative perspectives of her Bangladeshi culture, the opinions of Chanu, and most importantly, Nazneen's undecided position among these two points. An example of the multiple perspectives offered by the juxtaposition of memory and linear narrative is when Nazneen connects the memory of religious sadhus with the physically exposed tattoo woman. These two images cannot be different in any way more than they are, but due to her need to locate within her past identity in Bangladesh, she goes to the extent of merging images of covered women in her South Asian culture and the physically exposed bodies of their female counterparts in her host western culture. However, this association allows her to believe that she is still part of her Bangladeshi culture because at this point, she does not have anything else.

This constant desire experienced by many immigrants, including Nazeen, to cling to images of home and the memory of it has been critically examined for the past few decades through different lenses. An example of such an instance is during the group dinner conversation:

This is another disease that afflicts us, ... I call it Going Home Syndrome.” ... "It is natural," said Chanu. "These people are basically peasants and they miss the land. The pull of the land is stronger even than the pull of blood." ... "They don't ever really leave home. Their bodies are here, but their hearts are back there. And anyways, look how they live: just recreating the villages here (Ali 417).

It is important to notice that this "Going Home Syndrome" applies to all immigrants including Chanu and Dr. Azhad seen through the use of the pronoun "us". Chanu's specific description of the syndrome is referring to peasants and their pull to the land, a social class which he does not want to be associated with. However, Chanu also admits that one of his goals is to go back to Bangladesh, a symptom of the popular syndrome. In addition, the actual naming of the reaction immigrants have when entering a foreign country, and throughout their lives in it, allow us to see the extent of its importance. These immigrants see themselves more as migrants, with the possibility of going back to their homeland after accumulating some wealth. However, due to shattered beliefs and their current limited financial means, many immigrants extend their stay and rely on false hopes, as Chanu has chosen. In many cases, as Chanu states, these immigrant families will "recreate the villages here" in order to accommodate the loss of homeland and their constant memories of it. This allows them to create collective societies and form an abstract home away from home to treat their "Going Home Syndrome."

The need to preserve the memories they brought with them from home becomes more urgent then. As Memory, Narrative and Identity describes:

Ethnic values and traditions [that] never disappear; "there remains always, in every ethnic tradition, in the generational legacy of every individual family, a certain residue, a kind of ash, what I would call 'ghost-values': the tag ends and shreds and echoes of the past calling to us generations after their real force has been spent (Singh et al 8).

These generational beliefs are even stronger in the immigrants that Dr. Azhad and Chanu refer to, including Nazneen. Her memories of Islam and Bangladeshi society are vivid and strong, symbolising the strength of her connection to her roots. She even expresses her own desire to return back home when she suggests that they "would not need very much...and could live very cheaply" in order to save enough money and answer "the pull of the land" (Ali 417). Although her words go unrecognized, she is on the verge of being diagnosed with "going Home Syndrome" after which she will find it even more difficult to reform her identity to fit her home. 
Despite her desire to return to Bangladesh and constant recollection of memories, Nazneen's attempts to understand the western sport of figure skating, and specifically pronounce it, is representative of the beginning of her journey towards recreating a western identity. However, it is difficult not to acknowledge all the experiences she has had in her home and the memories she brings with her. In such situations, instead of embracing ethnic denial and forgetting, most [immigrants] struggle quite openly to maintain a 'double citizenship' or a kind of 'double consciousness' through contact with homelands, home cultures, and families overseas (Singh et al 7). This double citizenship is visible when analyzing Chanu and his ability to maintain a professional life, converse about his home, and be married to a Bangladeshi woman. Through his complaints about how his family at home presumes that he is swimming in money, we are able to see that he does maintain a line of communication with his home in Bangladesh. This allows him not only to be a Londoner and look forward to his promotion but also a Bangladeshi husband, son and brother. Even though Chanu does mention that he had promised himself he would go back home, this is not a central concern for him, especially when the discussion of his much contested promotion arises. Nazneen observes Chanu all throughout this interaction, from his curry stained shirt to the passion he feels when discussing the difficulties he had in London. With this experience, she is able to perceive the importance of being able to strongly support oneself in the society of London. Her lack of knowledge about the English language and culture are boundaries she must now surpass in order to form for herself an identity of double-consciousness. While she is not interested in the lecture Chanu gives her about Chaucer and Shakespeare, she is clearly interested in gaining more insight into the western culture to balance her understanding of the western culture with its eastern counterpart.

Nazneen's understanding of the western culture is just commencing, seen through a visual description and soon moving onto contextual knowledge provided by Chanu. Right from the beginning, she had offered us extremely vivid descriptions of the people she encounters and the images she sees - to the point where sometimes it slips into grotesqueness. But what must be focused upon and has been repeated throughout, is her tendency to associate her present events with memories. However, in the last few pages of the narrative when watching the figure skating competition on television, the images are there (as well as her vivid descriptions) but her memories no longer accompany them. She is fully engrossed in the reception of the sport and its novelty, through which we do slightly sense her cultural conservatism, but she is genuinely interested in learning about the sport itself. She first asks Chanu about it, and once she learns that what she has been intrigued by is ice-skating, she is able to articulate it, though with an incorrect pronunciation-- "ice e-skating" (Ali 421). This juxtaposition of western ice sport and eastern accent is symbolic of her commencement on a journey to create an identity of in-between(ness).

\section{Conclusion:}

Both Ganeshananthan's and Ali's narrators, Yalini and Nazneen, must re-evaluate their memories in order to construct identities that incorporate the various traumas they experience in order to assimilate into society. The traumas they experience are insidious in nature, they do have similar effects. They both experience displacement, as they are taken out of their natural environments and have the beliefs that they had held up to that point negated. While Yalini is aware of the ethnic conflict in Sri Lanka and the gruesomeness of the civil war taking place, her attempt to repress any such memories and form an American identity is thwarted once she encounters a wave of recollections in the Tamil populated Scarborough, Ontario. After receiving several accounts of life back home, she is able to incorporate these memories into her own and create a smooth interweave among them. Nazneen, however, must embark on her journey to create a new working identity predominantly on her own, due to the lack of a collective identity in her new London home. By analyzing the journey her husband Chanu's personal immigration narrative, she is able to navigate her new world in waves of "double-consciousness"--an ability not to be overpowered by the "pull of the land" but to find a comfortable balance between these two identities.

\section{References}

Ali, M. (2005). "Dinner With Dr.Azhad." Story-Wallah Short Fiction From South Asian Writers. Ed. Shyam Selvadurai. New York: Houghton Print.

Caruth, C. (1995). Trauma: Explorations in Memory. London: John Hopkins

Connerton, P. (1989). How Societies Remember. New York: Cambridge.

Ganeshananthan, V. V. (2008). Love Marriage. New York: Random House

Hunt, N. C. (2010). Memory, War and Trauma. New York: Cambridge

Singh, A., Joseph T. Skerrett Jr., and Robert E. Hogan, ed. (1994). Memory, Narrative and Identity. Boston: Northeastern

Xu, B. (1994). “Memory and the Ethnic Self: Reading Amy Tan's The Joy Luck Club. Melus. 19-1: 3-18. 